\title{
Agronomic performance and stability of andean common bean lines with white grains in Brazil
}

\author{
Helton Santos Pereira ( $\left.{ }^{1 *}\right)$; Luíce Gomes Bueno ( $\left.{ }^{1}\right)$; Maria José Del Peloso (1); \\ Angela de Fatima Barbosa Abreu ( $\left.{ }^{2}\right)$; José Aloísio Alves Moreira ( $\left.{ }^{3}\right)$; Maurício Martins $\left({ }^{4}\right)$; \\ Adriane Wendland ('); Luís Cláudio de Faria ('); Thiago Lívio Pessoa Oliveira de Souza ('); \\ Leonardo Cunha Melo (') \\ (') Embrapa Arroz e Feijão, Rod. GO 462, Km 12, 75375-000 Santo Antônio de Goiás (GO), Brasil. \\ (2) Universidade Federal de Goiás (UFG), Escola de Agronomia, Laboratório de Melhoramento Vegetal, Caixa Postal 131, 74001-970 \\ Goiania (GO), Brasil. \\ (3) Embrapa Milho e Sorgo, Rod. MG 424 Km 45, 35701-970 Sete Lagoas (MG), Brasil. \\ (4) Universidade Federal de Uberlândia (UFU), Av. João Naves de Ávila, 2121, 38408-100 Uberlândia (MG), Brasil. \\ (*) Corresponding author: helton.pereira@embrapa.br
}

Received: Oct. 14, 2013; Accepted: Mar. 1, 2014

\begin{abstract}
This work evaluated the effect of genotype by environment interaction in Andean common bean lines with white grains, in Central Southern Brazil, to identify lines with high agronomic performance, stability and adaptability, aiming to meet domestic demand and to increase the Brazilian participation in the foreign market of common bean. Nineteen trials with twelve Andean lines were conducted in 2007, 2008 and 2009, in Central Southern Brazil. Grain yield and other agronomic traits were evaluated. Data were subjected to analysis of variance and of adaptability/stability using Annicchiarico and modified AMMI methods. Significant differences were found between lines for all traits evaluated. Genotype by environment interaction was important for lines with Andean origin and white seed. The utilization of weighted mean of absolute scores and yield with the AMMl results enabled the identification of the most stable and adapted lines. Lines Poroto Alubia, CNFB 16211, Ouro Branco and WAF 160 were stable and adapted, using both methods. CNFB 16211 line presented high agronomic performance, stability and adaptability and therefore this line may be a new cultivar. USWA 70 and WAF 75 lines presented grain size similar to that required by the foreign market and superior to the Brazilian cultivars, besides favorable agronomic traits, and thus these lines may be indicated as new cultivars.
\end{abstract}

Key words: Phaseolus vulgaris, special grains, adaptability, genotype by environment interaction, AMMI.

\section{Potencial agronômico e estabilidade de linhagens de feijoeiro-comum de origem andina com grãos brancos no Brasil}

\section{Resumo}

Os objetivos deste trabalho foram avaliar o efeito da interação genótipos $x$ ambientes em linhagens de feijoeiro-comum de origem andina com grãos brancos na Região Centro-Sul do Brasil e identificar linhagens com alto potencial agronômico, estabilidade e adaptabilidade, visando atender a demanda interna e possibilitar a participação brasileira no mercado externo. Dezenove ensaios constituídos por 12 linhagens foram conduzidos em campo na Região Centro-Sul do Brasil nos anos 2007. 2008 e 2009. Avaliaram-se a produtividade de grãos e outros caracteres de importância agronômica. Os dados foram submetidos a análises de variância e de adaptabilidade/estabilidade pelos métodos de Annicchiarico e AMMl com modificações. Houve diferenças entre as linhagens para todos os caracteres avaliados. A interação genótipos $x$ ambientes foi importante na avaliação de linhagens de origem andina com grãos brancos. A utilização da média ponderada pelos escores absolutos e da produtividade com os resultados da análise AMMI facilitou a identificação de linhagens mais estáveis e adaptadas. As linhagens Poroto Alubia, CNFB 16211, Ouro Branco e WAF 160 são estáveis e adaptadas utilizando-se as duas metodologias. A linhagem CNFB 16211 apresenta alto potencial agronômico, alta estabilidade e adaptabilidade sendo, portanto, possível a sua indicação como nova cultivar. As linhagens USWA 70 e WAF 75 apresentam tamanho de grão semelhante ao exigido pelo mercado externo e superior ao das cultivares brasileiras, além de apresentarem caracteres agronômicos favoráveis, sendo portanto possível a sua indicação como novas cultivares.

Palavras-chave: Phaseolus vulgaris, grãos especiais, adaptabilidade, interação genótipos x ambientes, AMMI. 


\section{INTRODUCTION}

Common bean was domesticated independently in two centers of diversity, giving rise to two gene groups: Mesoamerican and Andean (Beebe et al., 2000). Differences between these groups can be checked in the morphology of the plant, seed size and type of phaseolin (reserve protein), among others. Andean lines have larger seed (100 seed weight above 30 grams) while Mesoamerican lines have smaller seed size (100 seed weight under 30 grams) (Gonzales et al., 2009).

Brazil is one of the largest producers and consumers of beans, which is the main source of vegetable protein for direct consumption of Brazilians. Carioca and black beans have Mesoamerican origin and represent $85 \%$ of Brazilian production. However there is increasing demand for production of other types of grains with higher added value and export possibilities (Del Peloso and Melo 2005). Among the commercial groups with higher international interest is the white group of Andean origin, with 55 to 59 grams per 100 seeds, consumed and marketed in Europe, Asia and the United States (Gonzales et al., 2009). Historically, breeding programs in Brazil have given low priority to Andean beans, including the white type, and as a result, few cultivars are available, which leads to low production and high import of this type of grain in Brazil. Currently, some breeding programs have focused on this type of grain, seeking to obtain and identify lines showing better adaptation to the soil and climatic conditions of the country (Gonçalves et al., 2010).

When breeding new cultivars, one of the main obstacles is the presence of the genotype by environment interaction ( $\mathrm{G} \times \mathrm{E})$. For the cultivation of common bean, numerous studies have shown the presence of such interaction, mainly for grain yield and with Mesoamerican lines (Melo et al., 2007; Pereira et al., 2011; 2012; Oliveira et al., 2006). Thus, one should seek alternatives to mitigate and/or take advantage from the interaction effects, including the use of methods for analysis of stability and adaptability, which provide detailed information about the behavior of cultivars, such as predictability and responsiveness to environmental variation (Cruz et al., 2004). Among the methods for studying stability, stands out the genotype recommendation index (Annicchiarico, 1992), for combining concepts of adaptability and stability into a single parameter (Pereira et al., 2009). Another methodology used in stability studies is the AMMI method (Additive Main Effects and Multiplicative Interactions) (Zobel et al., 1988), which allows a more detailed analysis of the $\mathrm{G} \times \mathrm{E}$ interaction.

These two methods are poorly correlated with each other and therefore can be used simultaneously (Melo et al., 2007; Pereira et al., 2009; Silva and Duarte, 2006). Among the few studies of this nature with Andean common bean (Gonçalves et al., 2010), none was performed with white grains. In this context and considering the above, the present study aimed to evaluate the importance of the genotype by environment interaction for Andean common bean lines with white grains in Brazil, identifying lines with high adaptability, stability and agronomic performance, aiming to meet domestic demand and to expand the Brazilian participation in the foreign market of this grain.

\section{MATERIAL AND METHODS}

Trials were performed in 2007, 2008 and 2009, in 19 environments, conducted in the winter sowing season in the states of Goiás and Minas Gerais (ten trials) and in the rainy and dry sowing season in the Paraná State (nine trials) (Table 1). Trials were installed according to procedures proposed by Melo (2009). The design was completely randomized blocks with three replications and plots consisted of four rows of four meters long. Each trial was formed by 12 common bean lines, 10 promising lines with white grains and two controls: Ouro Branco, a cultivar registered in Brazil with white grains and BRS Radiante, a cultivar of 'rajado' grains (cream with red stripes), of Andean origin, with excellent agronomic performance.

To assess agronomic performance, field evaluations were conducted in 19 trials for grain yield. For the other traits, the trials were evaluated whenever possible: lodging resistance (nine trials); plant architecture (eight trials); resistance to common bacterial blight (Xanthomonas axonopodis pv. phaseoli) (eight trials); reaction to angular leaf spot (Pseudocercospora griseola) (three trials); reaction to powdery mildew (Erysiphe polygoni) (seven trials); reaction to anthracnose (Colletotrichum lindemutianum) (three trials); and reaction to rust (Uromyces appendiculatus) (seven trials). These assessments were performed by means of rating scales described by Melo (2009), ranging from 1 (totally favorable phenotype) to 9 (totally unfavorable phenotype). It was also evaluated the weight of 100 seeds in three trials.

Data were subjected to analyses of variance considering the effect of mean and lines as fixed factors, and the others as random. In the combined analysis, the maximum $F$ test was run to check for homoscedasticity, given by the ratio between the highest and the lowest mean square residual (Pimentel-Gomes, 1990). Once detected heteroscedasticity, it was adjusted the degrees of freedom of the $\mathrm{GxE}$ interaction and of average error according to Cochran (1954). For evaluation of experimental precision, selective accuracy (SA) was estimated (Resende and Duarte, 2007), using the equation $S A=(1-(1 / F c))^{0.5}$, wherein: $F c=$ F-test value for the genotype, in which to $F_{c}<1, S A=0$. To compare means, the Scott-knot Test at $10 \%$ was used.

Adaptability and stability analysis were performed by the methods of Annicchiarico (1992) and AMMI (Zobel et al., 1988). The first considers the genotype recommendation index that estimates the risk of adopting a particular line. 
Table 1. Geographical information of sites and summary of individual analysis of variance for grain yield of 19 trials of common beans conducted in the states of Minas Gerais (MG), Goiás (GO) and Paraná (PR) in different sowing times

\begin{tabular}{|c|c|c|c|c|c|c|c|c|c|c|}
\hline Site/State ${ }^{(1)}$ & Alt ${ }^{(2)}$ & Lat. (3) & Long. ${ }^{(4)}$ & $\mathrm{QM}_{\mathrm{L}}{ }^{(5)}$ & $\mathrm{QM}_{\mathrm{E}}{ }^{(6)}$ & $\mathbf{P}^{(7)}$ & Média ${ }^{(8)}$ & CV ${ }^{(9)}$ & $F^{\text {(Genot) }}$ & SA \\
\hline \multicolumn{11}{|l|}{ Winter/2007 } \\
\hline Senador Canedo-GO & 801 & $16^{\circ} 42^{\prime}$ & $49^{\circ} 06^{\prime}$ & 189804 & 27915 & 0.0001 & 1708 & 9.8 & 6.80 & 0.92 \\
\hline Santo Antônio de Goiás-GO & 823 & $16^{\circ} 29^{\prime}$ & $49^{\circ} 17^{\prime}$ & 144063 & 129802 & 0.3989 & 1997 & 18.0 & 1.11 & 0.31 \\
\hline Urutaí-GO & 900 & $17^{\circ} 27^{\prime}$ & $48^{\circ} 12^{\prime}$ & 337886 & 156392 & 0.0598 & 3107 & 12.7 & 2.16 & 0.73 \\
\hline \multicolumn{11}{|l|}{ Rainy/2007 } \\
\hline Ponta Grossa-PR & 969 & $25^{\circ} 05^{\prime}$ & $50^{\circ} 09^{\prime}$ & 833343 & 56018 & 0.0000 & 2132 & 11.1 & 14.88 & 0.97 \\
\hline Guarapuava-PR & 1098 & $25^{\circ} 23^{\prime}$ & $51^{\circ} 27^{\prime}$ & 98188 & 19393 & 0.0006 & 757 & 18.4 & 5.06 & 0.90 \\
\hline Araucária-PR & 897 & $25^{\circ} 35^{\prime}$ & $49^{\circ} 24^{\prime}$ & 590592 & 85477 & 0.0001 & 2045 & 14.3 & 6.91 & 0.92 \\
\hline \multicolumn{11}{|l|}{ Dry/2008 } \\
\hline Araucária-PR & 897 & $25^{\circ} 35^{\prime}$ & $49^{\circ} 24^{\prime}$ & 446497 & 61124 & 0.0000 & 1915 & 12.9 & 7.30 & 0.93 \\
\hline Ponta Grossa-PR & 969 & $25^{\circ} 05^{\prime}$ & $50^{\circ} 09^{\prime}$ & 343795 & 111905 & 0.0120 & 2592 & 12.9 & 3.07 & 0.82 \\
\hline \multicolumn{11}{|l|}{ Winter /2008 } \\
\hline Senador Canedo-GO & 801 & $16^{\circ} 42^{\prime}$ & $49^{\circ} 06^{\prime}$ & 216163 & 99949 & 0.0595 & 1698 & 18.6 & 2.16 & 0.73 \\
\hline Itumbiara-GO & 448 & $18^{\circ} 25^{\prime}$ & $49^{\circ} 12^{\prime}$ & 191586 & 100162 & 0.0941 & 1578 & 20.1 & 1.91 & 0.69 \\
\hline Anápolis-GO & 1018 & $16^{\circ} 19^{\prime}$ & $48^{\circ} 57^{\prime}$ & 681207 & 287748 & 0.0411 & 3034 & 17.7 & 2.37 & 0.76 \\
\hline Uberlândia-MG & 863 & $18^{\circ} 55^{\prime}$ & $48^{\circ} 16^{\prime}$ & 464628 & 137826 & 0.0074 & 1667 & 22.3 & 3.37 & 0.84 \\
\hline Patos de Minas-MG & 832 & $18^{\circ} 34^{\prime}$ & $46^{\circ} 31^{\prime}$ & 49079 & 64600 & 1.0000 & 989 & 25.7 & 0.76 & 0.00 \\
\hline Lavras-MG & 919 & $21^{\circ} 14^{\prime}$ & $44^{\circ} 59^{\prime}$ & 696778 & 136305 & 0.0006 & 1866 & 19.8 & 5.11 & 0.90 \\
\hline Sete Lagoas-MG & 761 & $19^{\circ} 27^{\prime}$ & $44^{\circ} 14^{\prime}$ & 76776 & 24174 & 0.0101 & 1023 & 15.2 & 3.18 & 0.83 \\
\hline \multicolumn{11}{|l|}{ Rainy /2008 } \\
\hline Ponta Grossa-PR & 969 & $25^{\circ} 05^{\prime}$ & $50^{\circ} 09^{\prime}$ & 154229 & 20448 & 0.0000 & 1120 & 12.8 & 7.54 & 0.93 \\
\hline Araucária-PR & 897 & $25^{\circ} 35^{\prime}$ & $49^{\circ} 24^{\prime}$ & 199925 & 26089 & 0.0000 & 1250 & 12.9 & 7.66 & 0.93 \\
\hline \multicolumn{11}{|l|}{ Dry /2009 } \\
\hline Ponta Grossa-PR & 969 & $25^{\circ} 05^{\prime}$ & $50^{\circ} 09^{\prime}$ & 270703 & 96079 & 0.0186 & 1818 & 17.1 & 2.82 & 0.80 \\
\hline Araucária-PR & 897 & $25^{\circ} 35^{\prime}$ & $49^{\circ} 24^{\prime}$ & 121396 & 10740 & 0.0000 & 725 & 14.3 & 11.30 & 0.95 \\
\hline
\end{tabular}

${ }^{(1)}$ Municipality; ${ }^{(2)}$ Altitude (meters); ${ }^{(3)}$ South Latitude; ${ }^{(4)}$ West Longitude; ${ }^{(5)}$ Mean squared linhagens; ${ }^{(6)}$ Mean squared error; ${ }^{(7)}$ Probability associated with the source of variation lines; ${ }^{(8)}$ Overall mean of the trial $\left(\mathrm{kg} \mathrm{ha}^{-1}\right) ;{ }^{(9)}$ Coefficient of variation (\%); $\mathrm{F}^{(\mathrm{Genot})}$-F-test for the effect of lines; SA - Selective Accuracy

The stability is measured by the superiority of the lines in relation to the average of environments, associated with a given probability (Cruz et al., 2004). For AMMI (Additive Main Effects and Multiplicative Interactions), significance level was set at $5 \%$ according to the $\mathrm{F}_{\mathrm{r}}$ test criterion of Cornelius et al. (1992). Some studies have suggested adjustments to the AMMI method like the inclusion of additional genotype $(\mathrm{AG})$, to increase the precision of identifying superior lines (Pacheco et al., 2005). Pereira et al. (2009) suggested obtaining an index that considers the average of the absolute scores of each line in each significant component, weighted by the percentage of explanation of each significant component (AWAS), to facilitate the interpretation of results and identification of lines with high stability. Based on the AWAS index, the AWASY index wasproposed, which uses the weighted average of the absolute scores associated with the weighting of average yield of lines. This index allows the simultaneous evaluation of adaptability and stability associated with grain yield.

The identification of the most stable lines was based on the AWAS index of each line. Thus, the line with lower AWAS values is the most stable. The stability interpretation was also carried out through the graphical analysis, with the average of genotypes and AWAS. Lines closer to zero on the ordinate lines are the most stable, while those further away are those that contribute most to the interaction.

To combine stability with adaptability, we estimated the weighted average of the absolute scores associated with the weighting of average yield (AWASY) of lines, with weights equal to two and three, respectively. To obtain the AWASY, data of yield and AWAS were transformed to the same scale. The highest yield was considered $100 \%$ and the other values were obtained in relation to this. In the case of AWAS, all values were subtracted from 100 to reverse the rating scale, and then obtained the percentage relative to the highest value, for each line.

Analysis of variance and Annicchiarico were run in the application Genes (Cruz, 2001), and AMMI was performed in the SAS.

\section{RESULTS AND DISCUSSION}

There was a wide variation between mean values and between precision measurements for grain yield, evidencing the different conditions of the trials (Table 1). Average yields ranged from $725 \mathrm{~kg} \mathrm{ha}^{-1}$ to $3107 \mathrm{~kg} \mathrm{ha}^{-1}$, with coefficients of variation $(\mathrm{CV})$ equal to or lower than $26 \%$, and SA (selective 
accuracy) indicated high or very high accuracy in $85 \%$ of cases (Cargnelutti Filho and Storck, 2009).

The joint analysis detected significant differences $(\mathrm{p}<0.01)$ for environments and lines, which confirm the variation between the studied environments and genetic variability between lines (Table 2), as also reported by Gonçalves et al. (2010). For the other traits, significant differences were also verified between lines. There was great geographic variation between environments, once the altitude of the sites varied from $448 \mathrm{~m}$ to $1098 \mathrm{~m}$, besides differences of more than 9 degrees of latitude and more than 7 degrees of longitude (Table 1). Moreover, it was examined different years (2007, 2008 and 2009) and sowing times (rainy, dry and winter). The lines $\mathrm{x}$ environments interaction was significant and points out that, as usually found for Mesoamerican lines (Melo et al., 2007; Oliveira et al., 2006; Pereira et al., 2011; 2012), the performance of Andean lines in Central Southern Brazil is also influenced by the different response of lines to these environments, and therefore it is necessary to evaluate lines in several environments.

Average yields were lower (Table 3) than registered with Mesoamerican lines, in studies developed in the same regions (Melo et al., 2007; Oliveira et al., 2006; Pereira et al., 2011; 2012), validating the observation that Andean lines are less productive than Mesoamerican ones (Gonzales et al., 2009). The BRS Radiante control, which has 'rajado' grains, was the most productive line (2082 $\left.\mathrm{kg} \mathrm{ha}^{-1}\right)$, statistically different from other genotypes (Table 3). This was expected, since the breeding of 'rajado' beans in Brazil has already been done for a long time, and therefore there are available lines with good adaptation and higher performance than for white beans. The second group was formed by Poroto Alúbia and CNFB 16211, which surpassed the control Ouro Branco, being promising for grain yield. Between these two lines, the CNFB 16211 is among the most resistant to angular leaf spot, anthracnose and rust. Besides that, this line has erect plant architecture and good resistance to lodging, which results in lower grain loss at harvest and better quality grains. In relation to grain size, CNFB 16211 had size similar to that of Ouro Branco, thus being commercially acceptable.

The other lines were not different in grain yield from the control Ouro Branco, indicating that these lines have other favorable agronomic traits to justify their indication as new cultivars (Table 3). Regarding the resistance to diseases, most lines were resistant to anthracnose, angular leaf spot and rust, as well as Ouro Branco. However, few lines presented resistance to powdery mildew and common bacterial blight, highlighting the control BRS Radiante. In general, the lines WAF 170 and WAF 141 showed greater resistance to the diseases evaluated, but both had smaller grain size than the control Ouro Branco.

As for grain size, an essential trait for acceptance of cultivars of this grain (Gonzales et al., 2009), the line USWA 70 stood out for presenting the highest 100 seed weight among the lines evaluated and above that of the Ouro Branco. Additionally, this line has erect architecture and good resistance to lodging, angular leaf spot, anthracnose and rust. Another promising line in relation to grain size is the WAF 75 ( $57.7 \mathrm{~g} / 100$ seeds), which also has agronomic traits similar to that of USWA 70. It is noteworthy that the international market prefers grains slightly larger than that of Ouro Branco, and then lines USWA70 and WAF 75 have potential to meet this requirement. Recently, a new cultivar of white beans, named IPR Garça, was released, though it also has grain size similar to that of Ouro Branco.

The different responses of lines to environmental variation (Table 2) justify the need for stability and adaptability analysis. Using the method of Annicchiarico (1992) were identified the lines BRS Radiante, Poroto Alúbia and CNFB 16211 with recommendation index values (Wi) above $100 \%$,

Table 2. Combined analysis for grain yield $\left(\mathrm{kg} \mathrm{ha}^{-1}\right)$ of $19 \mathrm{VCU}$ trials of common beans, in 2007, 2008 and 2009, with breakdown of the interaction genotypes $\mathrm{x}$ environments into three axes of the interaction principal component analysis (IPCA), according to AMMI method

\begin{tabular}{|c|c|c|c|c|c|}
\hline SV & DF & SQ & MS & $\mathbf{F}$ & $\operatorname{Pr}>\mathrm{F}$ \\
\hline BLOCKS/ENV & 38 & 12526135 & 329635 & - & 0.000 \\
\hline Lines (L) & 11 & 13128287 & 1193481 & 8.77 & 0.001 \\
\hline Environments (E) & 18 & 301437716 & 16746540 & 123.02 & 0.000 \\
\hline LXA & $129^{(1)}$ & 49471397 & 383499 & 2.82 & 0.000 \\
\hline IPCA 1 & 28 & 16113236 & 575473 & 4.23 & 0.000 \\
\hline Residual 1 & 101 & 33358761 & 330285 & 2.43 & 0.000 \\
\hline IPCA 2 & 26 & 11381332 & 437744 & 3.22 & 0.000 \\
\hline Residual 2 & 75 & 21977429 & 293032 & 2.15 & 0.000 \\
\hline IPCA 3 & 24 & 5739341 & 239139 & 1.76 & 0.018 \\
\hline Residual 3 & 51 & 16238087 & 318394 & 2.34 & 0.000 \\
\hline Error & $267^{(1)}$ & 36347252 & 136132 & - & - \\
\hline TOTAL & 683 & 412934229 & - & - & - \\
\hline \multicolumn{6}{|c|}{ Mean: $1742 \mathrm{~kg} \mathrm{ha}^{-1}$ CV: $21.2 \%$} \\
\hline
\end{tabular}


Table 3. Average yield (AY) ( $\left.\mathrm{kg} \mathrm{ha}^{-1}\right)$, mean and maximum scores for resistance to lodging (RL), plant architecture (PA), reaction to common bacterial blight (CBC), angular leaf spot (ALS), powdery mildew (PM), anthracnose (AN), rust (RU) and 100 seed weight (100W) of 12 lines of common beans evaluated in 19 sites in the states of Goiás, Minas Gerais and Paraná (Brazil), in 2007, 2008 and 2009

\begin{tabular}{|c|c|c|c|c|c|c|c|c|c|c|c|c|c|c|c|c|c|}
\hline \multirow{2}{*}{ Genotype } & \multirow{2}{*}{\multicolumn{2}{|c|}{ AY }} & \multicolumn{2}{|c|}{ PA } & \multicolumn{2}{|c|}{$\mathbf{R L}$} & \multicolumn{2}{|c|}{ CBC } & \multicolumn{2}{|c|}{ ALS } & \multicolumn{2}{|c|}{ PM } & \multicolumn{2}{|c|}{ AN } & \multicolumn{2}{|c|}{ RU } & \multirow{2}{*}{$100 \mathrm{~W}$} \\
\hline & & & M & Max & M & Max & M & Max & M & Max & M & Max & M & Max & M & Max & \\
\hline BRS RADIANTE & 2083 & $\mathrm{a}$ & $3.8 \mathrm{~b}$ & 5 & $3.7 \mathrm{~b}$ & 5 & $3.4 \mathrm{a}$ & 6 & $3.7 \mathrm{~b}$ & 6 & $1.5 \mathrm{a}$ & 3 & $1.0 \mathrm{a}$ & 1 & $1.2 \mathrm{a}$ & 2 & $39.7 \mathrm{f}$ \\
\hline POROTO ALUBIA & 1912 & $b$ & $4.4 \mathrm{~b}$ & 7 & $4.6 \mathrm{c}$ & 8 & $5.0 \mathrm{~b}$ & 9 & $4.0 \mathrm{~b}$ & 7 & $5.3 c$ & 9 & $1.7 \mathrm{a}$ & 3 & $2.6 \mathrm{~b}$ & 5 & $51.8 \mathrm{c}$ \\
\hline CNFB 16211 & 1872 & $b$ & $3.4 \mathrm{a}$ & 5 & $3.2 \mathrm{~b}$ & 5 & $3.9 \mathrm{~b}$ & 7 & $2.4 \mathrm{a}$ & 5 & $5.4 \mathrm{c}$ & 8 & $1.0 \mathrm{a}$ & 1 & $2.2 \mathrm{~b}$ & 8 & $49.0 \mathrm{~d}$ \\
\hline OURO BRANCO & 1789 & c & $3.0 \mathrm{a}$ & 4 & $3.3 \mathrm{~b}$ & 6 & $4.1 \mathrm{~b}$ & 7 & $2.4 \mathrm{a}$ & 3 & $5.5 c$ & 8 & $2.0 \mathrm{a}$ & 4 & $1.2 \mathrm{a}$ & 3 & $49.3 d$ \\
\hline ALUBIA ARGENTINA & 1717 & c & $6.5 c$ & 7 & $6.1 \mathrm{~d}$ & 9 & $6.0 \mathrm{~b}$ & 9 & $6.3 c$ & 9 & $6.0 \mathrm{~d}$ & 9 & $9.0 \mathrm{~b}$ & 9 & $6.2 \mathrm{c}$ & 9 & $43.2 \mathrm{e}$ \\
\hline WAF 160 & 1693 & c & $4.1 \mathrm{~b}$ & 5 & $3.5 \mathrm{~b}$ & 8 & $4.9 \mathrm{~b}$ & 8 & $2.7 \mathrm{a}$ & 4 & $7.0 \mathrm{~d}$ & 9 & $1.0 \mathrm{a}$ & 1 & $1.2 \mathrm{a}$ & 3 & $47.8 \mathrm{~d}$ \\
\hline WAF 170 & 1666 & c & $4.5 \mathrm{~b}$ & 6 & $3.8 \mathrm{~b}$ & 5 & $2.6 \mathrm{a}$ & 4 & $2.7 \mathrm{a}$ & 6 & $2.7 \mathrm{~b}$ & 5 & $1.0 \mathrm{a}$ & 1 & $1.4 \mathrm{a}$ & 3 & $45.9 \mathrm{e}$ \\
\hline WAF 130 & 1654 & c & $3.8 \mathrm{~b}$ & 5 & $3.5 \mathrm{~b}$ & 6 & $5.0 \mathrm{~b}$ & 9 & $2.7 \mathrm{a}$ & 4 & $5.9 \mathrm{~d}$ & 9 & $1.0 \mathrm{a}$ & 1 & $1.0 \mathrm{a}$ & 1 & $46.8 \mathrm{~d}$ \\
\hline USWA 70 & 1648 & c & $3.2 \mathrm{a}$ & 5 & $2.8 \mathrm{a}$ & 4 & $4.3 \mathrm{~b}$ & 8 & $1.0 \mathrm{a}$ & 1 & $6.3 d$ & 9 & $1.0 \mathrm{a}$ & 1 & $1.0 \mathrm{a}$ & 1 & $64.5 \mathrm{a}$ \\
\hline WAF 75 & 1627 & c & $3.3 \mathrm{a}$ & 6 & $2.3 \mathrm{a}$ & 4 & $4.1 \mathrm{~b}$ & 9 & $2.7 \mathrm{a}$ & 6 & $4.5 \mathrm{c}$ & 8 & $2.3 \mathrm{a}$ & 5 & $1.2 \mathrm{a}$ & 3 & $57.7 \mathrm{~b}$ \\
\hline WAF 157 & 1624 & c & $4.3 \mathrm{~b}$ & 7 & $3.2 \mathrm{~b}$ & 6 & $4.1 \mathrm{~b}$ & 7 & $2.0 \mathrm{a}$ & 3 & $4.7 \mathrm{c}$ & 7 & $1.0 \mathrm{a}$ & 1 & $1.0 \mathrm{a}$ & 1 & $43.7 \mathrm{e}$ \\
\hline WAF 141 & 1623 & c & $3.6 \mathrm{a}$ & 5 & $2.9 \mathrm{a}$ & 5 & $2.6 \mathrm{a}$ & 4 & $1.4 \mathrm{a}$ & 2 & $3.7 \mathrm{~b}$ & 7 & $1.0 \mathrm{a}$ & 1 & $1.0 \mathrm{a}$ & 1 & $45.0 \mathrm{e}$ \\
\hline
\end{tabular}

indicating that these lines exceed the mean of environments in at least $15.6 \%, 7.2 \%$ and $1.8 \%$, respectively (Table 4 ). In favorable environments, lines BRS Radiante and CNFB 16211 continue to stand out, with $18.6 \%$ and $11.6 \%$ superiority, respectively.

In unfavorable environments, lines BRS Radiante, Poroto Alúbia and Alúbia Argentina exhibited the highest indices of stability/adaptability $(112.8 \%, 111.2 \%$ and $107.2 \%$, respectively) (Table 4). The classification of environment into favorable and unfavorable is based on the environments and generally, the reduction in grain yield reflects the sensitivity of lines to the effects of biotic (pests and diseases) and abiotic factors (water deficit, temperature stress, low soil fertility). Meanwhile, the line Alubia Argentina in spite of having good adaptability/stability to unfavorable environments, also showed the highest indices of susceptibility to diseases (Table 3). Importantly, the lines WAF 75 and WAF 170 also presented higher stability/adaptability in unfavorable environments compared to the control Ouro Branco. In general, lines Poroto Alubia and CNFB 16211 were also superior to the control Ouro Branco (Table 4).

Considering the AMMI analysis, the first three components were significant $(\mathrm{p}<0.05)$. According to Chaves (2001) the appropriate model is the one that associates significance to the axes and non-significance to the residuals, but it was found in this work the continued significance to the residuals, even after axes are no longer significant. In this way, as a model selection criterion, it was used the last axis with significance for the main component. In agreement with Arias et al. (1996) the use of models with more than three components, from the biological point of view, is unsatisfactory, besides being difficult to handle, in relation to the possible benefits. The first three axes together explained $67.2 \%$ of the variation $(\mathrm{PC} 1=32.6 \%$; $\mathrm{PC} 2=23.0 \%$ and PC3 $=11.6 \%$ ), similarly to values found by Carbonell et al.
(2004), Melo et al. (2007) and Pereira et al. (2009), in common beans.

Furthermore, with the significance level of 5\%, we selected the AMMI3 model (Table 2). Besides the possibility to reduce the occurrence of type II error (accepting a AMMI model with fewer axes when this is more parameterized), the adoption of this level resulted in higher approximation of the satisfactory percentage to the explanation of the variation of the interaction in the first axes. Thus the identification of the most stable axes was achieved with information of the first three components, using the weighted average of the absolute scores of each line (AWAS) (Table 4). The use of this parameter as stability measurement allows to present the mean stability and yield of the lines in a single graph, facilitating the combined analysis of the two parameters. By applying this parameter, the most stable lines were those with lower AWAS values. The most stable lines were WAF 160, WAF 170 and USWA 70, WAF 130, WAF 141 and WAF 75, (Table 4 and Figure 1). However, none of these are among the most productive, but all were more stable than the control Ouro Branco. The line of lowest stability was the BRS Radiante, which showed a higher average yield.

The AWASY index was used with the purpose to associate stability and average yield. With this, it was identified the control BRS Radiante as the one with higher stability and adaptability. Among the white grain lines, CNFB 16211, Poroto Alubia, WAF 160 and Ouro Branco were slightly superior to the others (Table 4). The line with the worst performance was the Alubia Argentina, a cultivar used in Argentina, which was very susceptible to diseases occurring in Brazil. This indicates the potential of these lines to be indicated as new and more adapted cultivars.

The application of the AWASY index enables aggregate methodological advantages of the AMMI analysis with information about average grain yield. Thus, it was possible 
Table 4. Estimates of parameters of adaptability and phenotypic stability by the Annicchiarico method (1992) ( $\mathrm{W}_{\mathrm{i}}$ - recommendation index), breakdown into favorable $\left(\mathrm{W}_{\mathrm{if}}\right)$ and unfavorable $\left(\mathrm{W}_{\mathrm{id}}\right)$ environments, and by the AMMI method, with values of the significant principal components (IPCA), indices AWAS (average weighted by the absolute scores) and AWASY (average weighted by the absolute scores and yield) and ratings of 12 lines of common beans evaluated in Central Southern Brazil, from 2007 to 2009

\begin{tabular}{|c|c|c|c|c|c|c|c|c|c|c|c|c|c|c|}
\hline \multirow[t]{2}{*}{ Genotype } & \multirow[b]{2}{*}{$\mathbf{Y}^{(1)}$} & & \multicolumn{6}{|c|}{ Annicchiarico (1992) } & \multicolumn{6}{|c|}{ AMMI } \\
\hline & & & $\mathbf{w}_{\mathbf{i}}$ & $\mathbf{C}^{(2)}$ & $\mathbf{w}_{\text {if }}$ & $\mathrm{C}$ & $\mathbf{W}_{\text {id }}$ & C & IPCA1 & IPCA2 & IPCA3 & AWAS & AWASY & C \\
\hline BRS RADIANTE & 2083 & $\mathrm{a}$ & 115.6 & 1 & 118.5 & 1 & 112.8 & 1 & 23.10 & 6.92 & -2.15 & 13.94 & 95.92 & 1 \\
\hline POROTO ALUBIA & 1912 & $b$ & 107.2 & 2 & 102.8 & 4 & 111.2 & 2 & -15.33 & -9.07 & 22.37 & 14.40 & 90.81 & 3 \\
\hline CNFB 16211 & 1872 & $b$ & 101.7 & 3 & 111.5 & 2 & 94.2 & 6 & 13.62 & 3.79 & 12.40 & 10.04 & 91.49 & 2 \\
\hline OURO BRANCO & 1789 & c & 96.0 & 4 & 103.2 & 3 & 90.2 & 8 & 16.15 & 8.90 & 3.61 & 11.50 & 88.49 & 5 \\
\hline WAF 160 & 1717 & c & 94.9 & 5 & 96.2 & 5 & 93.7 & 7 & -0.97 & -7.75 & 6.07 & 4.17 & 89.48 & 4 \\
\hline ALUBIA ARGENTINA & 1693 & c & 94.0 & 6 & 80.8 & 12 & 107.6 & 3 & -25.90 & 24.67 & -10.32 & 22.79 & 81.01 & 12 \\
\hline WAF 170 & 1666 & c & 91.8 & 7 & 87.4 & 10 & 95.9 & 5 & -5.27 & -10.15 & -10.53 & 7.85 & 86.45 & 6 \\
\hline WAF 130 & 1654 & c & 89.8 & 9 & 94.5 & 6 & 85.8 & 11 & 5.40 & 14.33 & 6.06 & 8.57 & 85.80 & 7 \\
\hline WAF 157 & 1648 & c & 89.7 & 10 & 90.0 & 8 & 89.3 & 9 & 2.98 & -23.96 & -7.52 & 10.95 & 84.64 & 11 \\
\hline USWA 70 & 1627 & c & 87.5 & 12 & 94.3 & 7 & 81.9 & 12 & 8.39 & 3.34 & -16.13 & 7.97 & 85.30 & 8 \\
\hline WAF 75 & 1624 & c & 91.3 & 8 & 85.9 & 11 & 96.7 & 4 & -16.12 & 1.60 & 5.00 & 9.22 & 84.69 & 10 \\
\hline WAF 141 & 1623 & c & 88.9 & 11 & 88.6 & 9 & 89.1 & 10 & -6.00 & -12.61 & -8.87 & 8.76 & 84.89 & 9 \\
\hline
\end{tabular}

${ }^{(1)}$ Means followed by the same letter are not significantly different by Scott-Knott test at $10 \%$ probability. ${ }^{(2)}$ Rating of genotypes as for stability, by the method of Annicchiarico (1992).

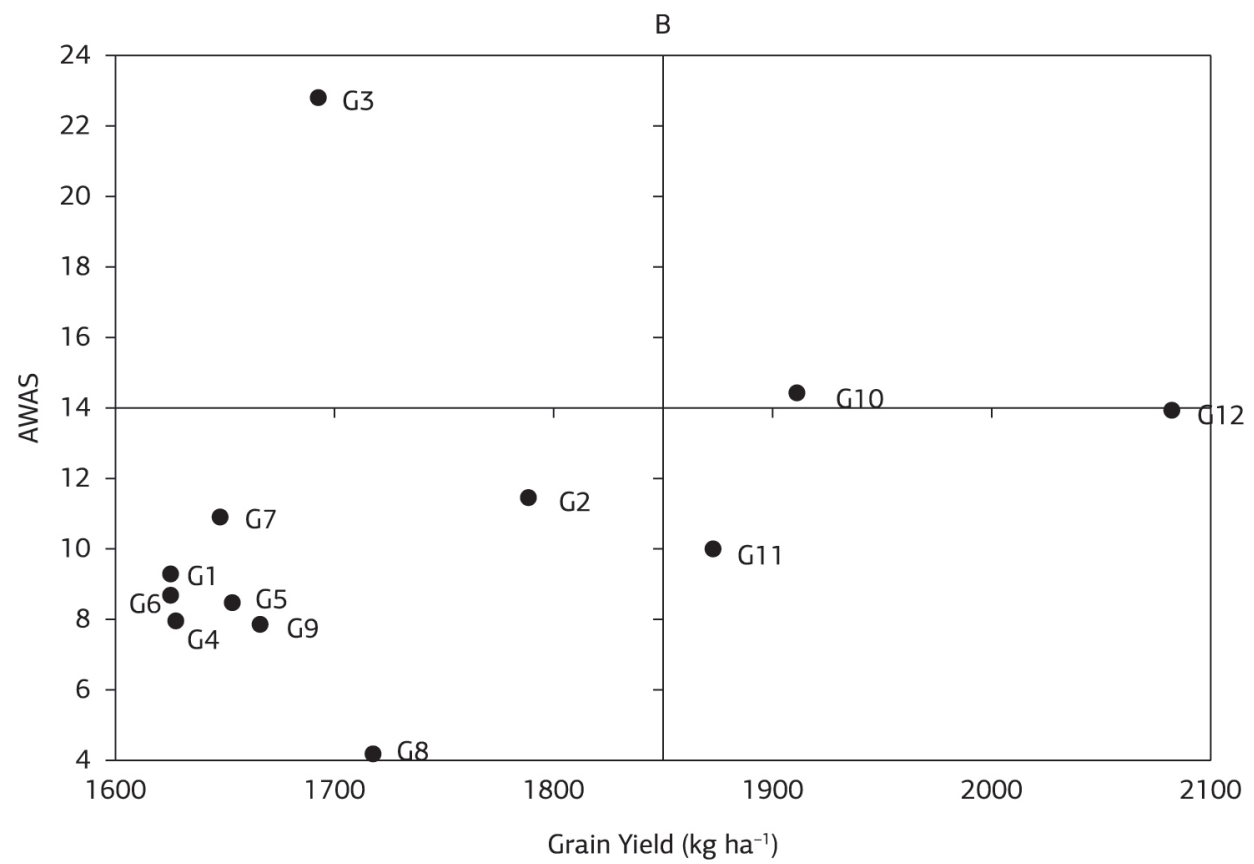

Figure 1. Graphical analysis of the AMMI of common bean lines (G1: WAF 75, G2: Ouro Branco, G3: Alubia Argentina, G4: USWA 70, G5: WAF 130, G6: WAF 141, G7: WAF 157, G8: WAF 160, G9: WAF 170, G10: Poroto Alubia, G11: CNFB 16211, G12: BRS Radiante) evaluated in 19 environments in Central Southern Brazil. Average yield $\left(\mathrm{kg} \mathrm{ha}^{-1}\right) \mathrm{x}$ average weighted by the absolute scores (AWAS).

to identify lines with improved performance, considering the stability and adaptability together. Greater similarity was also found between results of the Annicchiarico method and AWASY index, which strongly considers the average yield to obtain estimates of the stability/adaptability parameter.

Taking into account the stability analysis by the two methods, the lines Poroto Alubia, CNFB 16211, Ouro Branco and WAF 160 stand out (Table 4). When considering agronomic traits, the lines CNFB 16211, USWA 70, WAF 75 and WAF 141 stand out, since they show similar or better performance than the control Ouro Branco for eight out of nine traits evaluated (Table 3). Among them, it is worth highlighting USWA 70 and WAF 75, because they have grain size greater than that of Ouro Branco, which represents a great advantage for this commercial grain. The line CNFB 16211 is also noteworthy, since it shows grains and agronomic traits similar to those of Ouro Branco, and is among the most stable and adapted, and is more productive than the Ouro Branco. 


\section{CONCLUSION}

The genotypes by environments interaction is important in assessing lines of Andean common beans with white grains in Central Southern Brazil.

The use of AWASY combined with AMMI analysis facilitates the identification of more stable and adapted lines of common beans.

Lines Poroto Alubia, CNFB 16211, Ouro Branco and WAF 160 are the most stable and adapted, using the methods of Annichiaricco and AMMI.

The line CNFB 16211 has high stability and adaptability, grain and agronomic traits similar to those of Ouro Branco, and higher yield. Thus, it may be used as a new cultivar in the domestic market. The lines USWA 70 and WAF 75 have favorable agronomic traits and grain size similar to that required by the foreign market, superior to that of Ouro Branco, and may be indicated as new cultivars for export.

\section{ACKNOWLEDGEMENTS}

To Embrapa Rice and Beans, Embrapa Maize and Sorghum, Embrapa Technology Transfer - Ponta Grossa, EMATER-GO, EPAMIG, UFLA, UFU, Unicentro, IFETUrutaí, ILES/Ulbra for their support in developing the work and $\mathrm{CNPq}$ for scholarships for technological development and innovative extension and postdoctoral scholarship.

\section{REFERENCES}

ANNICCHIARICO, P. Cultivar adaptation and recommendation from alfafa trials in Northern Italy. Journal of Genetics and Plant Breeding, v.46, p.269-278, 1992.

ARIAS, E.R.A.; RAMALHO, M.A.P.; FERREIRA, D.F. Adaptabilidade e estabilidade de cultivares de milho avaliados no Estado de Mato Grosso do Sul. Ciência e Agrotecnologia, v.20, p.415-420, 1996.

BEEBE, S.E.; SKROCH, P.W.; TOHME, J.; DUQUE, M.C.; PEDRAZA, F.; NIENHUIS, J. Structure genetic diversity among common bean landraces of Mesoamerican origin based on correspondence analysis of RAPD. Crop Science, v.40, p.264-273, 2000. http://dx.doi.org/10.2135/cropsci2000.401264x

CARBONELL, S.A.M.; AZEVEDO FILHO, J.A.; DIAS, L.A.S.; GARCIA, A.A.F.; MORAIS, L.K. Common bean cultivars and lines interactions with environments. Scientia Agricola, v.61, p.169-177, 2004. http://dx.doi.org/=10.1590/S0103-90162004000200008

CARGNELUTTI FILHO, A.; STORCK, L. Medidas de precisão experimental em ensaios com genótipos de feijão e de soja. Pesquisa Agropecuária Brasileira, v.44, p.1225-1231, 2009. http://dx.doi. org/10.1590/S0100-204X2009001000003

CHAVES, L.J. Interação de genótipos com ambientes. In: NASS, L.L.; VALOIS, A.C.C.; MELO, I.S.; VALADARES-INGLES,
M.C. Recursos genéticos e melhoramento - plantas. Rondonópolis: Fundação, 2001. p.673-713.

COCHRAN, W.G. The combination of estimates from different experiments. Biometrics, v.10, p.101-129, 1954. http://dx.doi. org $/ 10.2307 / 3001666$

CORNELIUS, P.L.; SEYEDSADR, M.; CROSSA, J. Using the shifted multiplicative model to search for "separability" in crop cultivar trials. Theoretical and Applied Genetics, v.84, p.161-172, 1992. Pmid:24203043. http://dx.doi.org/10.1007/BF00223996

CRUZ, C.D. Programa Genes: aplicativo computacional em genética e estatística: versão Windows. Viçosa: Editora UFV, 2001. 648p.

CRUZ, C.D.; REGAZZI, A.J.; CARNEIRO, P.C.S. Modelos biométricos aplicados ao melhoramento genético. 3.ed. Viçosa: Editora UFV, 2004. v.1, 480p.

DEL PELOSO, M.J.; MELO, L.C. Potencial de rendimento da cultura do feijoeiro comum. Santo Antônio de Goiás: Embrapa Arroz e Feijão, 2005. 131p.

GONÇALVES, J.G.R.; CHIORATO, A.F.; MORAIS, L.K.; PERINA, E.F.; FARIAS, F.L.; CARBONELL, S.A.M. Estudo da estabilidade fenotípica de feijoeiro com grãos especiais. Ciência e Agrotecnologia, v.34, p.922-931, 2010. http://dx.doi.org/10.1590/ S1413-70542010000400018

GONZALES, A.M.; RODINÓ, A.P.; SANTALLA, M.; DE RON, A.M. Genetics of intra-gene pool and inter-gene pool hybridization for seed traits in common bean (Phaseolus vulgaris L.) germplasm from Europe. Field Crops Research, v.112, p.66-76, 2009. http:// dx.doi.org/10.1016/j.fcr.2009.02.003

MELO, L.C.; SANTOS, P.G.; FARIA, L.C.; DIAZ, J.L.C.; DEL PELOSO, M.J.; RAVA, C.A.; COSTA, J.G.C. Interação com ambientes e estabilidade de genótipos de feijoeiro-comum na Região Centro-Sul do Brasil. Pesquisa Agropecuária Brasileira, v.42, p.715-723, 2007. http://dx.doi.org/10.1590/S0100-204X2007000500015

MELO, L.C. Procedimentos para conduçáo de experimentos de Valor de Cultivo e Uso em feijoeiro comum. Santo Antônio de Goiás: Embrapa Arroz e Feijão, 2009. 104p. (Documentos, n.239)

OLIVEIRA, G.V.; CARNEIRO, P.C.S.; CARNEIRO, J.E.S.; CRUZ, C.D. Adaptabilidade e estabilidade de linhagens de feijão-comum em Minas Gerais. Pesquisa Agropecuária Brasileira, v.41, p.257-265, 2006. http://dx.doi.org/10.1590/S0100-204X2006000200010

PACHECO, R.M.; DUARTE, J.B.; VENCOVSKY, R.; PINHEIRO, J.B.; OLIVEIRA, A.B. Use of supplementary genotypes in AMMI analysis. Theoretical and Applied Genetics, v.110, p.812-818, 2005. http://dx.doi.org/DOI:10.1007/s00122-004-1822-6

PEREIRA, H.S.; MELO, L.C.; DEL PELOSO, M.J.; FARIA, L.C.; COSTA, J.G.C.; DÍAZ, J.L.C.; RAVA, C.A.; WENDLAND, A. Comparação de métodos de análise de adaptabilidade e estabilidade fenotípica em feijoeiro-comum. Pesquisa Agropecuária Brasileira, v.44, p.374-383, 2009. http://dx.doi.org/10.1590/S0100204X2009000400007

PEREIRA, H.S.; MELO, L.C.; DEL PELOSO, J.M.; FARIA, L.C.; FERREIRA, A.W. Complex interaction between genotypes and 
growing seasons of carioca common bean in Goiás/Distrito Federal. Crop Breeding and Applied Biotechnology, v.11, p.207-215, 2011. http://dx.doi.org/10.1590/S1984-70332011000300002

PEREIRA, H.S.; ALMEIDA, W.M.; MELO, L.C.; FARIA, L.C.; WENDLAND, A.; DEL PELOSO, M.J.; MAGALDI, M.C.S. Influência do ambiente em cultivares de feijoeiro-comum em cerrado com baixa altitude. Bragantia, v.71, p.165-172, 2012. http://dx.doi. org/10.1590/S0006-87052012005000024

PIMENTEL-GOMES, F. Curso de Estatística Experimental. 13.ed. Piracicaba: Nobel, 1990. 468p.
RESENDE, M.D.V.; DUARTE, J.B.D. Precisão e controle de qualidade em experimentos de avaliação de cultivares. Pesquisa Agropecuária Tropical, v.37, p.182-194, 2007.

SILVA, W.C.J.; DUARTE, J.B. Métodos estatísticos para estudo de adaptabilidade e estabilidade fenotípica em soja. Pesquisa Agropecuária Brasileira, v.41, p.23-30, 2006. http://dx.doi.org/10.1590/S0100204X2006000100004

ZOBEL, R.W.; WRIGHT, M.J.; GAUCH, H.G. Statistical analysis of a yield trial. Agronomy Journal, v.80, p.388-393, 1988. http:// dx.doi.org/10.2134/agronj1988.00021962008000030002x 